\title{
Aplication of videothoracoscopy in trauma - experience of a service
}

\section{Aplicação da videotoracoscopia no trauma - experiência de um serviço}

\author{
Bruno Vaz de Melo, tCBC-RJ'; Fellpe Guedes Siqueira ${ }^{1}$; Thales Siqueira Di Tano1; Paulo Oliveira Silveira'; \\ Mariama Barroso de Lima ${ }^{1}$
}

A B S T R A C T

\begin{abstract}
Objective: To evaluate patients with chest trauma submitted to videothoracoscopy during hospitalization. In 2007, the Trauma Surgery Group was created in the General Surgery Department of the Hospital Municipal Lourenço Jorge of Rio de Janeiro-RJ, and started following all trauma victims who were admitted to the Hospital. Methods: We conducted a retrospective analysis of patients submitted to thoracoscopy from July 2007 to May 2015, based on a database started at the beginning of this period and on data collection from patients who underwent thoracoscopy. We evaluated the following parameters: procedure effectiveness, indication of the procedure, conversion rate, complications and mortality. We included patients who presented post-traumatic pleural collections, such as retained hemothorax and pleural empyema, and penetrating injury in the thoracoabdominal transition. All patients were hemodynamic stable and signed an informed consent. Results: In the analyzed period 53 patients were submitted to videothoracoscopy; 24 had penetrating trauma (45.3\%) and 29, blunt (54.7\%), with a predominance of males (75.5\%). The procedure was performed in 26 cases of retained hemothorax (49\%), 14 cases of empyema (26.5\%) and in 13 patients for evaluation of injury in the thoracoabdominal transition (24.5\%). The thoracoscopy was effective in resolution of 36 cases ( $80 \%)$, without need for further procedure. There was a conversion rate of $15.5 \%$ and 3 procedure complications related (6.6\%). Mortality was nil. Conclusion: In this series, videothoracoscopy proved that this diagnostic and therapeutic procedure is safe and effective, if performed by a surgeon with appropriate training, especially when it is indicated in cases of retained hemothorax and evaluation of penetrating thoracoabdominal trauma.
\end{abstract}

Key words: Thoracoscopy. Thoracic Injuries. Thoracic Surgery, Video-Assisted. Hemothorax. Residual Volume.

\section{INTRODUCTION}

horacic trauma is present in approximately $30 \%$ of polytrauma patients. In most cases the injuries are treated conservatively or with simple procedures such as tube thoracostomy ${ }^{1}$. However, these cases are not exempted from complications and in some patients there is still need for additional procedures. The complications are related mainly to inadequate sterile techniques in emergency situations, incomplete evacuation of hemothorax, pain and displacement of chest tube ${ }^{2}$.

Over the last decades videothoracoscopy has been used for selected cases in some trauma centers, especially in North America and Europe, with publications from other centers as well. The first articles appeared three decades ago. From this period to the present day thoracoscopy has been used in many clinical situations in trauma patients ${ }^{3}$. Videothoracoscopy is a potential resource for various situations in trauma patients. It has been used both in the acute phase and in complications, either for diagnosis or treatment of post traumatic pleural collections, such as empyema and retained hemothorax, bleeding control, especially when the source is the chest wall, intrathoracic foreign body assessment, evaluation of diaphragm injury, especially in penetrating trauma of the thoracoabdominal transition, pulmonary parechyma and pericardium injuries, and bronchopleural fistula ${ }^{2,4,5}$.

The use of thoracoscopy in the acute phase is defended based on the possibility of diagnosing bleeding, pericardic and diaphragmatic injuries, which would not be detected if the trauma were treated with thoracostomy tube, and for the complete evacuation of the hemothorax, avoiding the most common complications $s^{6}$. Its early use may even reduce costs and radiation exposure, since it reduces observation time ${ }^{7}$.

The approach by thoracoscopy of the thoracic trauma complications also has had promising results in the centers where it has been used.

In this article we evaluate the results of thoracoscopy for the evaluation of thoracoabdominal trauma and treatment of complications of chest trauma, especially pleural collections.

1. Serviço de Cirurgia Geral e do Trauma do Hospital Municipal Lourenço Jorge, Rio de Janeiro, RJ, Brasil. 


\section{METHODS}

We conducted a retrospective analysis of cases in which thoracoscopy was used in victims of trauma. The study period was from July 2007 to May 2015. Data collection was performed on a database created at the beginning of the experiment and on assessment of patients' medical records. We assessed hospitalization time, complications, reoperations and death. All patients were followed on an outpatient basis after discharge; we recorded any sequelae and late complications. We considered the following variables: effectiveness of the method, indication of the procedure in our service, conversion rate to thoracotomy, complications and mortality associated with the procedure.

The inclusion criteria were: 1) patients sustaining penetrating thoracoabdominal injuries, who were hemodynamically stable, and previously submitted to thoracostomy with drainage in water seal, to assess the possibility of diaphragmatic injuries; 2 ) patients presenting with pleural complications of chest trauma: retained hemothorax, characterized by the presence of hemothorax and absence of lung expansion, over a period ranging from two days to four weeks, and patients with suspected pleural empyema or empyema unresolved by thoracostomy. All cases were documented with chest Computerized Tomography (CT).

All procedures were performed by the same surgical group. Most of them have experience in trauma surgery and laparoscopy, always trying to use the same technique, which was being standardized. Intubation was performed using a double-lumen endotracheal tube and positioning of the patient in the lateral position. In some situations, when for technical reasons selective intubation was not very effective, $\mathrm{CO}_{2}$ was injected in the pleural cavity (similar to the pneumoperitoneum) with a low pressure, always monitored by the anesthesia staff. in general, we chose initially to put the first $10-\mathrm{mm}$ trocar positioned at the previously made thoracostomy orifice and typically used two accessory trocars, preferably in the same intercostal space (anterior and posterior), the number of trocars being used as needed. We used only one monitor, which of course was positioned in the most ergonomic position for the surgeon and for a direct view. At the end of the procedure two chest tubes were positioned, one anteriorly and one posteriorly.

\section{RESULTS}

In this period, which was from July 2007 to May 2015, the Trauma Group followed 590 patients with thoracic trauma. We performed videothoracoscopy in 53 patients, all of them included in this analysis. Of this group, 42 patients were male (79\%), with mean age of 27 years. Blunt trau- ma constituted 29 cases (54.7\%), and penetrating, 24 (45.3\%).

The time for the procedure was variable, ranging from two days to four weeks, with a median of five days.

Regarding indications, videothoracoscopy was performed in 13 patients with penetrating thoracoabdominal trauma $(24.5 \%), 26$ patients with retained hemothorax (49\%) and 14 patients $(26.4 \%)$ with pleural empyema .

In patients suffering from thoracoabdominal injuries subjected to thoracoscopy for evaluation of diaphragm integrity $(n=13)$ there was positive lesion diagnosis in 6 patients (42.8\%). In five cases, diaphragmatic suture was performed by laparoscopic surgery. In one case, due to technical reasons and to extensive damage (about $10 \mathrm{~cm}$ ) a mini-thoracotomy was held to perform the diaphragm suture. Injuries to the diaphragm's costal portions are easier to view in our experience. In one patient we failed in properly evaluating the diaphragm (7\%) due to the presence of strong lung adhesions.

In the cases of retained hemothorax $(n=26)$ there was resolution in 25 patients (96.1\%). The one failure happened due to bleeding during the procedure, which led to conversion to thoracotomy. We observed a greater technical ease in patients for whom the same procedure was indicated earlier ( $<5$ days). The overall hospital stay after thoracoscopy averaged five days.

In cases with pleural empyema, the procedure was performed in 14 patients. Some of these cases were made later (transferred patients, patients returned to the hospital after discharge, ICU patients with multiple trauma in need of delaying intervention). In many cases the indication was delayed (four weeks for one patient). The worst results were obtained in this group, for which six conversions were necessary, mainly related to empyema in stage III with pulmonary incarceration and technical impossibility of safe thoracoscopy, leading to conversion in a number considered high (42.8\%).

The procedure was effective in $86.7 \%(n=53)$ of patients and the best results were obtained in patients in whom it was performed earlier ( $<5$ days) (Table 1$)$.

The conversion rate was $13.2 \%$, predominantly in cases of empyema and late indications. There were complications in three $(5.6 \%)$ patients: one bleeding of lung parenchymal injury in the passage of the trocar, one postoperative broncho-pleural fistula and one iatrogenic injury to the diaphragm. (Table 2). Mortality was nil.

\section{DISCUSSION}

In most cases of chest trauma that require any intervention, thoracostomy with water seal drain is enough. But in cases where this does not happen, the procedures that are usually adopted are invasive and increase 
Table 1 - Efficacy of thoracoscopy in trauma.

\begin{tabular}{lcrr}
\hline & Total & \multicolumn{2}{c}{ Resolution (\%) } \\
\hline Retained Haemothorax & 26 & 25 & $(96.1)$ \\
Empyema & 14 & 8 & $(57.1)$ \\
Thoracoabdominal Injury & 13 & 11 & $(84.6)$ \\
TOTAL & 53 & 44 & $(83)$ \\
\hline
\end{tabular}

Source: General Surgery and Trauma of Hospital Municipal Lourenço Jorge (07 / 2007-05 / 2015).

significantly the length of hospital stay and treatment costs. In the literature these cases can reach $20 \% 1,8$. Videothoracoscopy has been used as an option in this scenario, proving to be applicable both as a diagnostic and as a therapeutic approach ${ }^{4}$, as in most cases in our series. Although little used by surgeons in trauma, in our reality it is a procedure that, with proper training, can be widely used, presenting no great implementation complexity.

The cases of retained hemothorax appear as a great indication of videothoracoscopy. Our series, despite being small, reaffirms what has already been shown by the medical literature in the last decades. In most cases there is resolution, reduced hospital stay and consequently lower treatment costs. The early approach, in the first 3-7 days, provides better results according to a study on the subject ${ }^{9}$, although some authors indicate the fifth day of evolution as the cutoff point to significant worsening of results 8 . In the cases reviewed in our service there were similar results. The extended period of evolution leads to loculation of collections and lung entrapment, bringing additional technical difficulty to the procedure and reducing its effectiveness. The thoracoscopy for thoracic trauma with retained hemothorax displays $10 \%$ of failure in published works ${ }^{2}$.

In penetrating injuries of the thoracoabdominal transition, the diaphragm evaluation is difficult when using non-invasive methods, chest X-ray and $C T$, and other described methods do not have acceptable accuracy, sometimes reaching levels below $50 \%^{6}$. Early diagnosis of diaphragmatic injuries is an important prognostic factor. Thoracoscopy allows accurate diagnosis of such lesions when properly performed and also allows the correction to be carried out without additional intervention. Martinez et al. presented a case series of 52 patients with penetrating thoracoabdominal trauma, with diaphragm injuries diagnosis in $67.3 \%{ }^{10}$. Divisi et al. point at lesions larger than $3 \mathrm{~cm}$ as the single therapeutic limit ${ }^{6}$. Despite the lower incidence of diaphragmatic injury in our study, there was success in repair by thoracoscopy in most diagnosed cases, the lesion size being the limiting factor found. We believe that thoracoscopy is a safe and effective method for the diagnosis and treatment of lesions of the diaphragm.

The empyema is a complication mostly associated with retained hemothorax. Karmy-Jones et al. showed a higher incidence of empyema in patients undergoing thoracostomy with retained hemothorax over those without hemothorax ${ }^{2}$. Other factors associated with the development of empyema are inadequate aseptic technique in emergency situations and lung infections associated with hospital stay ${ }^{1,2}$. The most commonly identified agent was Staphylococcus aureus. The treatment of pleural empyema consists in evacuating the chest secretion and decortication in some cases ${ }^{11}$. Thoracoscopy in these cases shows bad results. Despite being a minimally invasive technique, less traumatic than thoracotomy, it has high failure and conversion rates, especially when performed in later stages. However, thoracoscopy was superior than the treatment with thoracic drainage associated with antibiotics; therefore, it is a valid surgical option before considering thoracotomy ${ }^{9}$. Our experience, although small, has results similar to the literature, with high conversion rates, especially when the indication is late. In the early stages, we had good results and the procedure was technically simpler. Patients with empyema at later stages seem to be a group with higher chances of failure. Early indications for the procedure, as demonstrated in several series of literature and in ours, is an important factor for treatment success of and for the best results obtained with this technique.

We conclude, despite the small number of this series, that thoracoscopy is a feasible procedure with multiple indications and applications in trauma patients, and in our series there was a low rate of complications and no mortality.

Table 2 - Conversion rate to thoracotomy.

\begin{tabular}{llrrrr}
\hline & N & Conversions (\%) & \multicolumn{2}{c}{ Conversion rate $(\%)$} \\
\hline Retained Haemothorax & 26 & 1 & $(3.9)$ & 1 & $(3.9)$ \\
Empyema & 14 & 6 & $(42.8)$ & 2 & $(14.2)$ \\
Thoracoabdominal INJURY & 13 & 1 & $(7.6)$ & 1 & $(7.6)$ \\
TOTAL & 53 & 8 & $(15)$ & 4 & $(7.5)$ \\
\hline
\end{tabular}

Source: General Surgery and Trauma of Hospital Municipal Lourenço Jorge (07 / 2007-05 / 2015). 


\section{R E S U M O}

Objetivo: avaliar os resultados obtidos com o emprego da videotoracoscopia na avaliação dos traumas toracoabdominais e no tratamento das complicações do trauma torácico. Métodos: análise retrospectiva dos pacientes submetidos à videotoracoscopia no período de julho de 2007 a maio de 2015, com base em banco de dados criado no início deste período e na coleta dos dados dos pacientes submetidos à videotoracoscopia. Foram avaliados: a eficácia e as indicações do procedimento, a taxa de conversão, as complicações e mortalidade. Foram incluídos os pacientes que apresentavam coleções pleurais pós-traumáticas, como hemotórax retido e empiema pleural, e lesões penetrantes na transição toracoabdominal. Todos os pacientes submetidos apresentavam estabilidade hemodinâmica e consentimento informado do procedimento. Resultados: no período analisado, 53 pacientes foram submetidos à toracoscopia, dentre estes, 24 traumas penetrantes (45,3\%) e 29 contusos (54,7\%) com predominância do sexo masculino (75,5\%). O procedimento foi realizado em 26 casos de hemotórax retido (49\%), 14 empiemas (26,5\%) e em 13 pacientes para avaliação de lesões da transição toracoabdominal (24,5\%). A toracoscopia foi eficaz na resolução de 36 casos (80\%) sem necessidade de novo procedimento. Houve uma a taxa de conversão de $15,5 \%$ e três complicações relacionadas ao procedimento (6,6\%). A mortalidade foi nula. Conclusão: apesar da série ainda ser pequena, a videotoracoscopia é um procedimento factível, com várias indicações e aplicações em pacientes traumatizados e, na nossa série, a mortalidade foi nula e a incidência de complicações, pequena.

Descritores: Toracoscopia. Traumatismos Torácicos. Cirurgia Torácica Videoassistida. Hemotórax. Volume Residual.

\section{REFERENCES}

1. Smith JW, Franklin GA, Harbrecht BG, Richardson JD. Early VATS for blunt chest trauma: a management technique underutilized by acute care surgeons. J Trauma. 2011;71(1):102-5; discussion 105-7.

2. Karmy-Jones R, Holevar M, Sullivan RJ, Fleisig A, Jurkovich GJ. Residual hemothorax after chest tube placement correlates with increased risk of empyema following traumatic injury. Can Respir J. 2008;15(5):255-8.

3. Dorgan Neto V, Saad Júnior R, Rasslan S. Videotoracoscopia no trauma de tórax. Rev Col Bras Cir. 2001;28(1):3-8.

4. Schermer CR, Matteson BD, Demarest GB 3rd, Albrecht RM, Davis $\mathrm{VH}$. A prospective evaluation of video-assisted thoracic surgery for persistent air leak due to trauma. Am J Surg. 1999;177(6):4804.

5. Rasslan S, Rodrigues FCM, Soldá SC, Saad Júnior R. Corpo estranho intratorácico tratado por videocirurgia. Rev Col Bras Cir. 1994;21(1):42-4.

6. Divisi D, Battaglia C, De Berardis B, Vaccarili M, Di Francescantonio W, Salvemini S, et al. Video-assisted thoracoscopy in thoracic injury: early or delayed indication? Acta Biomed. 2004;75(3):158-63.

7. Ahmed N, Chung R. Role of early thoracoscopy for management of penetrating wounds of the chest. Am Surg. 2010;76(11):12369.
8. Morales Uribe CH, Villegas Lanau MI, Petro Sanchez RD. Best timing for thoracoscopic evacuation of retained post-traumatic hemothorax. Surg Endosc. 2008;22(1):91-5.

9. Mowery NT, Gunter OL, Collier BR, Diaz JJ Jr, Haut E, Hildreth A, et al. Practice management guidelines for management of hemothorax and occult pneumothorax. J Trauma. 2011;70(2):5108.

10. Martinez M, Briz JE, Carillo EH. Video thoracoscopy expedites the diagnosis and treatment of penetrating diaphragmatic injuries. Surg Endosc. 2001;15(1):28-32; discussion 33.

11. Aguilar MM, Battistella FD, Owings JT, SU T. Posttraumatic empyema. Risk factor analysis. Arch Surg. 1997;132(6):647-50; discussion 650-1.

Received: 08/12/2014

Accepted for publication: 25/02/2015

Conflict of interest: none.

Source of funding: none.

Mailing address:

Felipe Guedes Siqueira

E-mail: felipeguedess87@gmail.com 